\title{
Correlation Analysis for Seed Yield and Its Attributing Traits in Soybean (Glycine max L. Merrill)
}

\author{
Preeti Painkra*, Rajeev Shrivatava, Sunil Kumar Nag and Ishu Kute \\ Department of Genetics and Plant Breeding, College of Agriculture, IGKV, \\ Raipur (C.G.) 492012, India \\ *Corresponding author
}

\section{A B S T R A C T}

\begin{tabular}{|l|}
\hline K e y w o r d s \\
$\begin{array}{l}\text { Soybean germplasm, } \\
\text { Correlation coefficient, } \\
\text { Positive and negative } \\
\text { association, Significant } \\
\text { association }\end{array}$ \\
\hline Article Info \\
\hline $\begin{array}{l}\text { Accepted: } \\
\text { 16 March } 2018 \\
\text { Available Online: } \\
\text { 10 April 2018 }\end{array}$ \\
\hline
\end{tabular}

\section{Introduction}

Soybean (Glycine max L. Merrill) is the most important oilseed crop in all over the world. It serves as oil seed crop, feed for live-stock and aquaculture, a good source of protein for the human diet and as a biofuel feedstock (Masuda \& Goldsmith 2009). As the best source of protein it truly claims the title "the meat that grows on plant". It contains 40 to $42 \%$ good quality protein and 18 to $22 \%$ oil comprising $85 \%$ unsaturated fatty acids and is free from cholesterol along with ample mineral elements, so it is highly desirable in human diet.
It is usually grown for its seed protein and oil. For protein sources, it can be used in different ways, such as soy milk, soy meat, snaps, tofu, etc. For oil source, some products have been produced from soybean oil, such as cooking oil, margarine, cosmetics, biodiesel, etc. Besides these products, it can also be used as soy ink. Although demand for soybean has been increased, the genetic improvement for soybean cultivars is extremely narrow. There are several limitations for soybean production such as low yield, susceptibility to pests and diseases and adverse environmental conditions, etc. The knowledge of certain genetic parameters is essential for proper 
understanding and their manipulation in any crop improvement programme. Seed yield is the result of the expression and association of several plant growth components.

Correlation coefficients, although useful in quantifying the size and direction of trait associations, can be misleading if the high correlation between two traits is a consequence of the indirect effect of the traits (Dewey \& Lu, 1959). Thus, knowledge of the relationship between those characteristics that make up the final yield of soybean genotype is important in enabling a more precise identification of the components that can determine a more productive plant.

Keeping in view the importance of this technique the present study was planned to investigate the genetic parameter, correlation coefficient analysis along with genetic traits to identify the best genotypes on the basis of results for future exploitation.

\section{Materials and Methods}

The experimental material of the present study comprised of 273 germplasm lines of soybean including three checks in augmented design divided into 6 blocks and every block has 47 entries and three checks but 12 entries were not germinated obtained from AICRP on soybean, Department of Genetics and Plant Breeding, Indira Gandhi Krishi Vishwavidyalaya, Raipur, Chhattisgarh, India. Each entry was raised in three rows, $2 \mathrm{~m}$ length spaced at $30 \mathrm{~cm}$ and $20 \mathrm{~cm}$ between plants, respectively. The recommended packages of practices for soybean cultivation were followed for raising a healthy crop. The crop was sown in the field on $27^{\text {th }}$ June 2015.

Correlation coefficients were calculated for all possible combinations among all the thirteen characters at phenotypic and genotypic levels as per the formula given by Searle (1961).
The significance of correlation coefficients was tested against Fisher's table value for (n2) degree of freedom at 5 per cent and 1 per cent level of significance, where $n$ is the number of genotypes.

The observations were recorded on thirteen quantitative traits namely, days to $50 \%$ flowering, days to maturity, plant height $(\mathrm{cm})$, number of primary branches per plant, pod bearing length $(\mathrm{cm})$, number of pod bearing node, number of pods per plant, number of seeds per pod, number of seed per plant, 100seed weight (g) Seed yield per plant (g), protein content (on moisture free basis) and oil content.

\section{Results and Discussion}

Correlation coefficient is a measure of degree and direction of linear relationship in between two variables. Many economically important traits of plants are usually related to one another in one or several ways. The correlation coefficient of different traits on seed yield per plant $(\mathrm{g})$ was given in Table 1 and only significant correlation was described as under:

\section{Seed yield per plant (g)}

Seed yield per plant (g) estimated highly significant and positive association with following traits viz., numbers of pods per plant (0.780), number of seeds per pod (0.524), number of seeds per plant (0.898) and100 seed weight (0.557) whereas, negative association estimated with number of pod bearing nodes (-0.126).

\section{Days to $50 \%$ flowering}

Days to $50 \%$ flowering was estimated highly significant and positive association with days to maturity (0.243), plant height (0.247), number of primary branches per plant $(0.247)$, 
pod bearing length (165), number of pod bearing nodes (0.241), number of seeds per pod $(0.178)$, protein content $(0.231)$ and oil content (0.212).

\section{Days to maturity}

Days to maturity was estimated highly significant and positive association with plant height (0.20), pod bearing length (0.302) and oil content (0.215).

Whereas it showed significant positive association with number of pod bearing nodes $(0.150)$ and protein content $(0.142)$.

\section{Plant height (cm)}

Plant height showed highly significant and positive association with pod bearing length (0.813), number of pod bearing nodes (0.327), number of pods per plant $(0.161)$ and protein content (0.160) and significant positive association oil content $(0.120)$.

\section{Number of primary branches per plant}

The primary branches per plant showed highly significant and positive association with number of pod bearing nodes (0.230), number of seeds per pod (0.338), protein content (0.280), oil content (0.256) and significant positive association with number of seeds per plant (0.142).

\section{Pod bearing length (cm)}

Pod bearing length $(\mathrm{cm})$ showed significant and positive association with number of pod bearing nodes (0.236), number of pods per plant (0.232), number of seeds per plant (0.161) and significant positive association with protein content $(0.142)$ and oil content (0.135).

Fig.1 Association among yield and major contributing traits

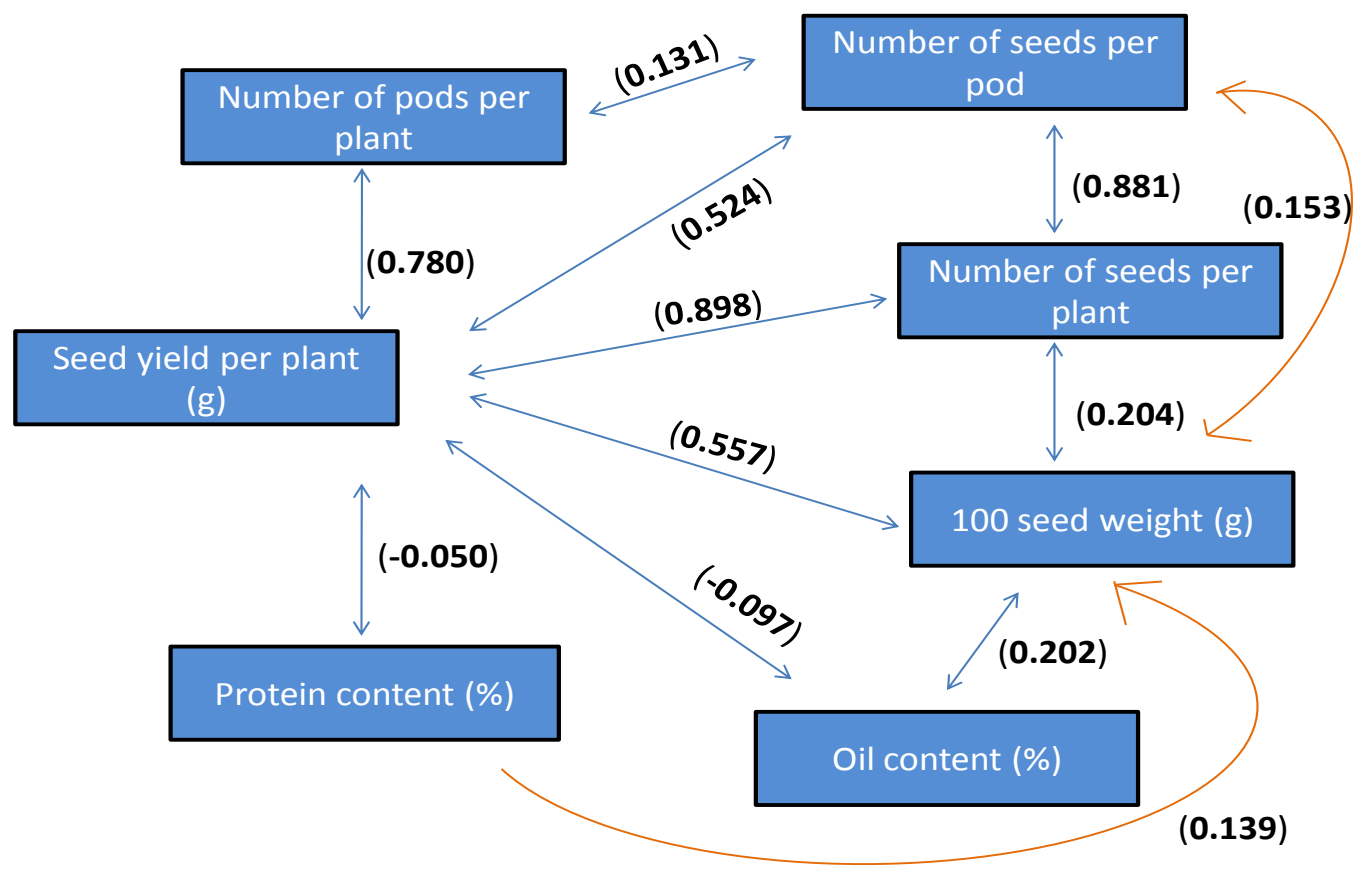


Table.1 Correlation matrix for seed yield and its contributing traits in soybean germplasm accession

\begin{tabular}{|c|c|c|c|c|c|c|c|c|c|c|c|c|}
\hline Characters & $\begin{array}{l}\text { Seed yield } \\
\text { per plant } \\
\text { (g) }\end{array}$ & $\begin{array}{c}\text { Days to } \\
50 \% \\
\text { flowering }\end{array}$ & $\begin{array}{l}\text { Days to } \\
\text { maturity }\end{array}$ & $\begin{array}{l}\text { Plant } \\
\text { height } \\
(\mathrm{cm})\end{array}$ & $\begin{array}{l}\text { Number } \\
\text { of } \\
\text { primary } \\
\text { branches } \\
\text { per plant }\end{array}$ & $\begin{array}{l}\text { Pod } \\
\text { bearing } \\
\text { length } \\
(\mathrm{cm})\end{array}$ & $\begin{array}{c}\text { Number } \\
\text { of pod } \\
\text { bearing } \\
\text { nodes }\end{array}$ & $\begin{array}{l}\text { Number } \\
\text { of pods } \\
\text { per plant }\end{array}$ & $\begin{array}{l}\text { Number } \\
\text { of seeds } \\
\text { per pod }\end{array}$ & $\begin{array}{l}\text { Number } \\
\text { of seeds } \\
\text { per plant }\end{array}$ & $\begin{array}{c}100 \\
\text { seed } \\
\text { weight } \\
(\mathrm{g})\end{array}$ & $\begin{array}{l}\text { Protein } \\
\text { content } \\
(\%)\end{array}$ \\
\hline $\begin{array}{l}\text { Days to } 50 \% \\
\text { flowering }\end{array}$ & 0.019 & & & & & & & & & & & \\
\hline Days to maturity & -0.036 & $0.243^{* *}$ & & & & & & & & & & \\
\hline Plant height(cm) & 0.002 & $0.247^{* *}$ & $0.272^{* *}$ & & & & & & & & & \\
\hline $\begin{array}{l}\text { Number of } \\
\text { primary branches } \\
\text { per plant }\end{array}$ & $0.146^{*}$ & $0.247^{* *}$ & 0.096 & -0.039 & & & & & & & & \\
\hline $\begin{array}{l}\text { Pod bearing } \\
\text { length }(\mathrm{cm})\end{array}$ & 0.084 & $0.165^{* *}$ & $0.302^{* *}$ & $0.813^{*}$ & -0.020 & & & & & & & \\
\hline $\begin{array}{l}\text { Number of pod } \\
\text { bearing nodes }\end{array}$ & $-0.126^{*}$ & $0.241^{* *}$ & $0.150^{*}$ & $0.327^{*}$ & $0.230^{* *}$ & $0.236^{* *}$ & & & & & & \\
\hline $\begin{array}{l}\text { Number of pods } \\
\text { per plant }\end{array}$ & $0.780^{* *}$ & 0.039 & 0.052 & $0.161^{*}$ & 0.020 & $0.232^{* *}$ & -0.028 & & & & & \\
\hline $\begin{array}{l}\text { Number of seeds } \\
\text { per pod }\end{array}$ & $0.524^{* *}$ & $0.178^{* *}$ & 0.090 & 0.036 & $0.338^{* *}$ & 0.018 & 0.054 & $0.131^{*}$ & & & & \\
\hline $\begin{array}{l}\text { Number of seeds } \\
\text { per plant }\end{array}$ & $0.898^{* *}$ & 0.060 & 0.012 & 0.100 & $0.142^{*}$ & $0.161^{* *}$ & -0.059 & $0.881^{* *}$ & $0.537^{* *}$ & & & \\
\hline 100 seed weight(g) & $0.557^{* *}$ & 0.036 & -0.044 & -0.080 & 0.116 & -0.043 & -0.069 & $0.153^{*}$ & $0.237^{* *}$ & $0.204^{* *}$ & & \\
\hline $\begin{array}{l}\text { Protein content } \\
(\%)\end{array}$ & -0.050 & $0.231^{* *}$ & $0.142^{*}$ & $0.160^{*}$ & $0.280^{* *}$ & $0.142^{*}$ & $0.255^{* *}$ & -0.025 & $0.223^{* *}$ & 0.037 & $0.139^{*}$ & \\
\hline Oil content (\%) & -0.097 & $0.212^{* *}$ & $0.215^{* *}$ & $0.120^{*}$ & $0.256^{* *}$ & $0.135^{*}$ & $0.180^{* *}$ & 0.005 & $0.226^{* *}$ & 0.062 & $0.202^{*}$ & -0.047 \\
\hline
\end{tabular}

**and * Significant at $\mathrm{P}=1 \% \& 5 \%$ level, respectively 


\section{Number of pod bearing nodes}

Number of pod bearing nodes had highly significant and positive association with protein content $(0.255)$ and oil content $(0.180)$.

\section{Number of pods per plant}

Number of pods per plant showed highly significant and positive association with seed yield per plant (0.881), whereas it showed significant positive association with number of seeds per pod (0.131) and 100 seed weight (g) (0.153).

\section{Number of seeds per pod}

Number of seeds per pod had highly significant and positive association with seed yield per plant (0.537), 100 seed weight $(0.237)$, protein content $(0.223)$ and oil content (0.226).

\section{Number of seeds per plant}

Number of seeds per pod had highly significant and positive association with 100 seed weight (0.204).

\section{0 seed weight $(g)$}

100 seed weight $(\mathrm{g})$ had highly significant and positive association with oil content (0.202) and significant positive association with protein content (0.139) (Fig. 1).

\section{Protein content (\%)}

Protein content $(\%)$ had negative association with oil content $(-0.047)$.

A positive significant correlation between desirable traits is favourable because it helps in simultaneous improvement of both the characters. On the other hand, negative correlation will hinder the simultaneous expression of both characters with high values. In such situation some economic compromise has to be made. The seed yield per plant $(\mathrm{g})$ recorded highly significant and positive association with number of pods per plant (0.780), number of seeds per pod (0.524), number of seeds per plant $(0.898)$ and 100 seed weight $(0.557 \mathrm{~g})$ (Table 1$)$. This indicated that simultaneous selection for these traits might bring an improvement in seed yield. Rajanna et al., (2000) estimated significant and positive correlation of number of pods per plant, number of clusters per plant and 100-seed weight with seed yield. Chamnundeswari and Aher (2003) for seed yield showed positive correlation with number of pods per cluster, number of clusters per plant, number of pods per plant and biological yield per plant.

Dev et al., (2005) reported with significant positive correlations of seed yield with biological yield and pods per plant. Ghodrati (2013) found strong positive significant correlation between seed yield and plant height. Shaahu et al., (2013) for seed yield was highly significant and positively correlated with pods per plant. Silva et al., (2014) that the number of pods/plant showed the highest and positive correlation with the seed yield per plant while 100-seed weight had high and negative correlation. Jain et al., (2015) for seed yield per plant had positive significant correlation with biological yield, number of pods per plant and 100 seed weight indicating that an intense selection for these characters will improve seed yield in soybean. These results are in conformity with the findings of several workers, who have reported significant correlation for seed yield per plant $(\mathrm{g})$ and its component traits in different studies for number of branches per plant, days to $50 \%$ flowering and days to maturity, plant height, 100-seed weight, biological yield and harvest index 
(Shrivastava et al., 2001; Chettri et al., 2003; Malik et al., 2007; Aditya et al., 2011; Badawy and Mehaen, 2012; Badkul et al., 2014; Chandel et al., 2014; Ali et al., 2015; Nagarajan et al., 2015 and Pushpendra et al., 2015). The results obtained in the present investigation clearly indicated that improvements in seed yield are simultaneously possible through indirect selection for number of pod per plant which is highly correlated with seed yield.

\section{Acknowledgment}

Author is grateful to Major Advisor Dr. Rajeev Shrivastava for their guidance and support during the research work along with Mr. Sunil Kumar Nag for providing the material and assisting the research works. HOD, Deptt. Of Genetics and Plant Breeding and whole members who were supported and cooperated while author was working on research at College of Agriculture, IGKV, Raipur (C.G.).

\section{References}

Aditya, J. P., Bhartiya, P. and Bhartiya, A. 2011. Genetic variability, heritability and character association for yield and component characters in soybean (Glycine max L. Merrill). Journal of Central European Agriculture, 12(1): 27-34.

Badawy, M. and Mehasen, S. A. S. 2012. Correlation and path coefficient analysis for yield and yield components of soybean genotypes under different planting density. Asian J. Crop Sci., 4 (4): 150-158.

Badkul, A., Shrivastava, A. N., Bisen, R. and Mishra, S. 2014. Study of principal components analyses for yield contributing traits in fixed advanced generations of soybean (Glycine max L. Merrill). Soybean Res., 2: 44-50.
Chandel, K. K., Patel, N. B. and Patel, J. B. 2014. Correlation Path Coefficients and Analysis in Soybean (Glycine max L. Merrill). An International e Journal, 3: 25-31.

Chettri, M., Mondal, S. and Nath, R. 2003. Studies on correlation and path analysis in soybean in the Darjeeling hills. $J$. Hill Res., 16(2): 101-103.

Dev, V., Hooda, J. S. and Malik, B. P. S. 2005.Variability and association studies in soybean (Glycine $\max$ L. Merrill). Crop Res., 29 (2): 247-251.

Dewey, J.R. and K.H. Lu. 1959. A correlation and path co-efficient analysis of components of crested wheat seed production. Agron. J., 51: 515-518.

Ghodrati, G. H. 2013. Study of genetic variation and broad sense heritability for some qualitative and quantitative traits in soybean (Glycine max L. Merrill) genotypes. Current Opinion in Agriculture, 2(1): 31-35.

Jain, S., Srivastava, S. C., Singh, S. K., Indapurkar, Y. M. and Singh, B. K. 2015. Studies on genetic variability, character association and path analysis for yield and its contributing traits in soybean (Glycine max L. Merrill). Legume Res., 38(2): 182-184.

Malik, M. F. A., Ashraf, M., Qureshi, A. S. and Ghafoor, A. 2007. Assessment of genetic variability, correlation and path analyses for yield and its components in soybean. Pakistan J. Bot., 39(2): 405413.

Masuda, T. and Goldsmith, P.D. 2009. World Soybean production: Area harvested, yield, and long-term projections. International Food and Agribusiness Management Review 12: 143-162.

Nagarajan, D., Kalaimagal, T. and Murugan, E. 2015. Correlation and path coefficient analysis for yield and yield attributes in soybean (Glycine $\max \mathrm{L}$. 
Merrill). International Journal of Farm Sciences, 5(3): 28-34.

Pushpendra, A., Singh, K., Gupta, M. K. and Bhareti, P. 2015. Morphological characterization and genetic divergence study in soybean. Soybean Res., 13(2):1-8.

Searle, S. R. 1961. Phenotypic, Genetic and Environmental Correlations. Biometrics, 17 (3): 474-480.

Shaahu, A., Bello, L. L. and Vange, T. 2013. Correlation, path coefficient and principal component analysis of seed yield in soybean genotypes. Indian $J$. Adv. Res., 1(7): 1-5.

Shrivastava, M. K., Shukla, R. S. and Jam, P. K. 2001. Path co-efficient analysis in diverse genotype of soybean (Glycine $\max$ L. Merrill). Adv. Plant Sci., 14(1): 47-51.

Silva, A. F., Sediyama, T., Silva, F. S. C., Bezerra, A. R. G. and Ferreira, L. V. 2014. Correlation and path analysis of soybean yield components. International Journal Plant Animal and Environmental Sciences, 5(1): 175-179.

\section{How to cite this article:}

Preeti Painkra, Rajeev Shrivatava, Sunil Kumar Nag and Ishu Kute. 2018. Correlation Analysis for Seed Yield and Its Attributing Traits in Soybean (Glycine max L. Merrill). Int.J.Curr.Microbiol.App.Sci. 7(04): 2034-2040. doi: https://doi.org/10.20546/ijcmas.2018.704.234 